\title{
Killer Cell Lectin-Like Receptor Subfamily B Member 1
}

National Cancer Institute

\section{Source}

National Cancer Institute. Killer Cell Lectin-Like Receptor Subfamily B Member 1. NCI

Thesaurus. Code C26477.

Killer cell lectin-like receptor subfamily B member 1 (225 aa, $\sim 25 \mathrm{kDa}$ ) is encoded by the human KLRB1 gene. This protein plays a role in the modulation of natural killer cell cytotoxicity. 